\title{
Comédia, leituras e representações do teatro de Eugène Scribe na Corte brasileira'
}

\author{
Denise Scandarolli \\ (Unicamp/Unasp-EC)
}

Resumo: A chegada de duas companhias francesas de teatro no Rio de Janeiro, nos anos de 1840 , modificaram profundamente as práticas artísticas da cidade, tanto no que diz respeito aos hábitos de representação das peças, como ao desenvolvimento de mecanismos de controle para garantir a boa prática dos teatros na Corte, como veículo de difusão de moral e não de subversão da mesma. Neste contexto, as obras de Eugène Scribe tem grande impacto, provocando embates entre a nascente crítica teatral dos Folhetins e os censores do Conservatório Dramático Nacional, a partir de 1844. Assim, este artigo busca entender as modificações dos significados das obras de Scribe para os censores e os críticos teatrais do Rio de Janeiro.

Palavras-Chave: Teatro francês, Eugène Scribe, música, representação

COMEDY, READINGS AND REPRESENTATIONS OF EUGÈNE SCRIBE'S THEATER IN THE BRAZILIAN COURT

Abstract: The arrival of two French theatre companies in Rio de Janeiro, in the 1840s, changed the artistic practices of the city, both in habits of theatrical words representation as the development of control mechanisms to safeguard the good practices of the Court theatres, as a device for the transmission of moral and not as a subversion of the same. In this context, Eugène Scribe's works have great impact; it causes objections between the theatre of Folhetins and the censors of the National Dramatic Conservatory, from 1844. Thus, this article seeks to understand the changes of Scribe's works signification to the censors and the theatre critics of Rio de Janeiro.

Keywords: French Theatre, Eugène Scribe, Music, Representation

\footnotetext{
1 Este artigo foi apresentado no Congresso Internacional As práticas da Comédia, que aconteceu em Lisboa, em julho de 2013.
} 
Os anos de 1840 foram fundamentais para a arte e o teatro no Rio de Janeiro, período em que os espetáculos, o público, a crítica e a censura da corte brasileira começam a se definir e a fazer parte do processo de construção de uma identidade nacional. Várias vertentes explicativas devem ser consideradas na tentativa de compreender o que proporcionou o florescer das artes teatrais naquele momento, como a maior estabilidade do Estado se comparado com a aparente instabilidade do período Regencial, cuja figura do poder central não encontrava força simbólica na minoridade de D. Pedro II; ou como o amadurecimento de algumas instituições, por exemplo, a Academia de Belas Artes, estruturada pelos artistas da questionada Missão Francesa² de Joachim Lebreton; ou a necessidade apresentada pela nova elite da corte de espetáculos aos moldes daqueles produzidos nos teatros europeus, como dispositivo civilizatório, para que a corte brasileira, por meio dos hábitos, alcançasse o padrão de civilidade fornecido pelo modelo europeu.

O teatro, sobretudo o teatro musical, também era visto na Europa como regulador dos costumes ${ }^{3}$ e a consciência dos homens de letras brasileiros desta função social do teatro reafirma a interação que existia entre os discursos aquém e além mar. Boa parte da elite da corte realizava sua formação acadêmica no exterior, por isso seus questionamentos eram mais diálogos com as elites letradas europeias do que mera reprodução de discursos em voga no velho mundo. Sendo assim, as práticas sociais europeias não eram simples modelos a ser imitado no Brasil, mas se configuravam como as próprias práticas e hábitos dos cidadãos ${ }^{4}$ da corte brasileira que eram, em sua maioria, europeus imigrados e filhos de europeus, claro que adaptados à realidade encontrada no Rio de Janeiro.

\footnotetext{
${ }^{2}$ A legitimidade da ida dos artistas franceses para o Rio de Janeiro como uma Missão Artística encomendada por D. João VI é ponderada principalmente no trabalho de Lilian Schwartz, no livro O Sol do Brasil: Nicolas-Taunay e as desventuras dos artistas franceses na corte de D. João.

3 Sobre este tema, ver SENNETT, R. O declínio do homem público: as tiranias da intimidade; GAY, Peter. O século de Schnitzler. A formação da cultura da classe média 1815 - 1914; ELIAS, Norbert. Mozart, sociologie d'un génie.

${ }^{4} \mathrm{O}$ conceito de cidadão exclui os que não tinham direitos civis, no caso do Brasil deste período, os escravos africanos e os índios.
} 
A emancipação política do território brasileiro, em 1822, e a instituição do Império Brasileiro deu origem a novas necessidades, como a regulamentação das práticas sociais da corte e, sobretudo, a estruturação do brasileiro em distinção ao português. Neste contexto, o teatro era tido como importante protagonista. $\mathrm{O}$ principal teatro da corte, o teatro de São Pedro de Alcântara, ${ }^{5}$ ocupou um lugar central na política desde a instalação da Família Real Portuguesa no país. O teatro funcionava como a representação simbólica do poder e magnitude do Imperador, ${ }^{6}$ já que era palco de todas as manifestações de solenidade e festejos do Estado. Entretanto, enquanto núcleo artístico, os artistas que detinham sua concessão não conseguiam estruturar temporadas coesas de apresentações, oferecendo espetáculos esparsos, com raras obras inéditas; a base do repertório era formada de dramas, restando apenas a apresentação de poucas árias de óperas para o teatro musical. A falta de artistas e de aprimoramento dos mesmos tornava difícil a encenação de peças líricas na íntegra.

A baixa frequência de espetáculos e de obras inéditas refletia no desenvolvimento da crítica dos teatros, que se mantinham irregulares nas publicações dos periódicos da corte. Apesar da existência de outras salas de espetáculo na cidade, as principais atuações artísticas aconteciam no Teatro de São Pedro de Alcântara, por isso a preocupação de regulamentação dos espetáculos se restringia ao teatro principal e ignorava os poucos outros teatros sem muita expressividade.

É exatamente nesse contexto que chega ao Rio de Janeiro, em julho de 1840, uma companhia de teatro formada na França, por artistas deste país, oriundos dos teatros de Paris, a Companhia Dramática Francesa (Compagnie Dramatique Française). Logo em seguida, em 1846, outro grupo de artistas franceses se instala no Rio de Janeiro, a Companhia Lírica Francesa (Compagnie Lyrique Française).

\footnotetext{
${ }^{5}$ Este teatro foi inaugurado em 1813 , com o nome de Real teatro de São João e fazia parte das modificações da cidade do Rio de Janeiro corte, para sediar a Família Real Portuguesa, que lá estava desde 1808. Passou a Imperial Teatro de São Pedro de Alcântara, em 1826; depois a teatro Constitucional Fluminense, em 1831 e voltando a se chamar Teatro de São Pedro de Alcântara, em 1839.

${ }^{6}$ Sobre o tema ver MALERBA, 2000.
} 
Estes dois grupos de artistas franceses apresentam uma nova dinâmica teatral à corte, incitando profundas mudanças tanto no que diz respeito às práticas artísticas, como à expansão das normas legais de utilização das salas e de autorização de conteúdos dos espetáculos para outros teatros, desenvolvendo a crítica teatral em publicações nos principais jornais da corte, além dos mecanismos de regulamentação do teatro como formador social.

No contexto destas mudanças, este artigo vai abordar as relações estabelecidas entre as comédias de Eugène Scribe, a crítica musical e a censura teatral do Conservatório Dramático Nacional questionando como as peças de Scribe, encenadas pelos artistas franceses, provocaram importantes questionamentos sobre os caminhos literários e teatrais brasileiros, assim como o impacto dessas produções criaram a necessidade da formulação de regras para a apresentação de espetáculos, expandindo o controle já existente no Teatro de São Pedro de Alcântara para os demais teatros do Rio de Janeiro.

\section{As companhias francesas e as obras de Eugène Scribe}

A Companhia Dramática Francesa se instalou no teatro de São Januário, um pequeno teatrinho na praia de São Manoel, de 1840 a 1846; e a Companhia Lírica Francesa, permaneceu de 1846 a 1848 nos teatros de São Januário e, posteriormente, no teatro de São Francisco, sala de espetáculo de pequenas proporções construída ao lado do teatro de São Pedro de Alcântara. Estas companhias trouxeram para o Brasil dois gêneros de teatro musical franceses, o vaudeville e o opéra-comique. Ambos os gêneros têm a mesma origem, as feiras de Paris. São peças com característica cômica, cuja dramaturgia tem como objeto principal as estruturas sociais e hábitos das classes dominantes e da burguesia urbana, descritos por meio de caricaturas que marcam as personagens e as linhas musicais escolhidas, no caso do vaudeville, ou as composições originais, no caso dos opéra-comiques.

As formas e estruturas desses dois gêneros se definiram durante o século XVIII e início do XIX, passando de gênero "baixo" a representação do genuíno 
teatro francês, no século XIX, quando se definem como gêneros distintos, com a ascensão a teatro nacional do Opéra-Comique, em 1801 e do Vaudeville, em 1830.

Apesar de já ter havido representações de alguns dramas franceses nos teatros do Rio de Janeiro, a chegada da Companhia Dramática Francesa, sob a direção de Ernest Gervaise, apresenta uma grande modificação na realidade teatral da corte. Pela primeira vez chega à corte uma companhia teatral bem estruturada, contando com 22 artistas, que possuíam um repertório pré-estabelecido e bastante específico.

Além disso, a companhia francesa impôs um ritmo de apresentação nunca experimentado pelo público fluminense. Enquanto o teatro principal, o São Pedro de Alcântara, apresentava uma média de 3 peças inéditas por ano, o grupo francês começou a apresentar por volta de 3 novas peças por espetáculo, de um total de 2 espetáculos por semana, as quartas e sábados, chegando ao fim de 6 meses com um número surpreendente de peças apresentadas, principalmente para o público do Rio de Janeiro, do início do século XIX. De agosto a dezembro de 1840, a Companhia Dramática Francesa apresentou 82 vaudevilles e opéra-comiques, dos quais 58 foram estreias; em 1841, foram 206 apresentações e 127 estreias; em 1842 foram 128 apresentações e 87 estreias; em 1843 foram 160 apresentações e 87 estreias, em 1844 foram 134 apresentações e 46 estreias; em 1845 foram 45 apresentações e 30 estreias; em 1846, já com a Companhia Lírica Francesa, foram 54 apresentações e 21 estreias; em 1847 foram 123 apresentações e 22 estreias; em 1848 foram 8 apresentações e 6 estreias. Entre as várias peças apresentadas, um número considerável delas é de autoria de Eugène Scribe, cerca de 43 comédias e 62 vaudevilles e opéra-comiques. Apesar de haver um número alto de comédias, as obras que mais repercussão trouxeram para a crítica e a censura foram os vaudevilles e os opéra-comiques. Em estimativa, de 1840 a 1846 , período de predominância de vaudevilles, 53\% eram de autoria de Eugène Scribe; e de 1846 a 1848, período em que foram colocados em cena maioritariamente opéra-comiques, $80 \%$ das peças tinham texto desse autor e $60 \%$ delas eram acompanhadas de música de Daniel François Esprit Auber. 
Scribe encabeça uma nova geração de vaudevillistas que reformularam a estrutura do gênero até então popular. Ele começou a trabalhar para o teatro do Vaudeville por volta de 1810, e ajudou a fazer crescer o vaudeville de costumes, o qual tendeu a se aproximar da comédia de intriga, se afastando do estilo imposto no período revolucionário de peças heroicas, anticlericais e patrióticas.

Em parceria principalmente com Auber, Scribe desenvolveu importantes opéra-comiques, a ponto de ser considerado por teóricos como Gérard de Nerval (1989, p. 785), crítico e literato do século XIX, como o criador de um gênero único de opéra-comique, “ao qual Auber soube aplicar uma música apropriada e segura que agradou ao público e deste conjunto espiritual e harmonioso resulta vários sucessos".

Apesar da dificuldade imposta por um teatro musicado apresentado em francês, os literatos brasileiros acreditavam manter um diálogo proveitoso com as correntes de pensamento francesas, o que possibilitava a eles tecer argumentos e apontar características, como sobre os "ultrarromânticos", ou se colocarem a par dos discursos de nação e de arte nacional, além de interagirem com eles trabalhando-os dentro da realidade encontrada no Brasil.

No entanto, quando o teatro francês começa a ser representado na corte brasileira, por artistas franceses, esse teatro se transformou no "outro", criando um tipo de relação de alteridade que reforçou a visão dos literatos brasileiros sobre a criação de um teatro nacional, num movimento paradoxal renegando os gêneros franceses, mesmo mantendo o discurso que ressaltava a importância da língua para a cultura e do exemplo de "civilidade". Mesmo conscientes da conta que mantinham com a França, a chegada de uma companhia francesa de teatro funcionou como um espelho que refletia as diferenças na própria imagem da corte brasileira. E reforçava os problemas que os ideais franceses representavam para os ideais de moral que a elite brasileira tentava manter.

Essas peças tinham sido concebidas como reflexão e crítica a hábitos e costumes bastante distintos dos brasileiros. Enquanto os franceses, no início do século XIX, haviam acabado de passar por movimentos que desestruturaram a corte e a igreja, o Brasil buscava se encontrar como nação independente e forjar 
uma aristocracia, com bases fundadas no catolicismo herdado da antiga colonização.

O maior desafio que o teatro francês tinha que enfrentar ao representar nas salas de espetáculo fluminenses era a adequação de suas práticas e hábitos às normas vigentes. O deslocamento do repertório não estava à mercê apenas de ajustes técnicos referentes às estruturas físicas, como os teatros, palcos, vestimentas, cenários, etc.; a adaptação aos costumes e aos valores da corte brasileira pode ser considerada como o maior dos problemas para a permanência da companhia francesa no Rio de Janeiro.

Neste sentido é que as peças de Scribe desencadeiam consideráveis reflexões por parte da elite intelectual brasileira. Entretanto, a difusão do teatro francês na primeira metade do século XIX não estava restrita ao Brasil, mas começava a se tornar um fenômeno bastante amplo, com companhias francesas apresentando-se da América ao Oriente. A questão é que o repertório francês difundia certa visão de homem e de sociedade que se pode qualificar como "progressista", por isso que certos autores dramáticos que eram considerados na França como conservadores, são percebidos como de vanguarda política e intelectual no exterior. Eugène Scribe é um dos exemplos mais emblemáticos dessa mudança de significação das considerações valorativas, pois na França ele é estigmatizado pelos românticos franceses que o julgam como "burguês", com conotação pejorativa, por outro lado, no Brasil, ele é elogiado como o autor que melhor descreve e critica a vida e os costumes burgueses da sociedade francesa.

\section{Folhetim, censura e Eugène Scribe}

À medida que o interesse do público pelo teatro francês ganhava força, crescia também a preocupação governamental em regulamentar os espetáculos oferecidos no Rio de Janeiro, como já acontecia no teatro de São Pedro de Alcântara desde o final da década de 1830.

Em uma carta de 1839, recebida pelo conselheiro Cândido José de Araújo Viana, visconde de Sapucaí, e enviada do Paço Imperial, é enfatizada a 
necessidade de submissão prévia a exames de uma comissão as peças que se pretendiam encenar no teatro de São Pedro. Os objetivos desse exame prévio, de acordo com a carta, eram que não aparecessem em cena assuntos, nem mesmo expressões menos "conformes com o decoro, os costumes, e as atenções, que em todas as ocasiões devem guardar, e maiormente naquelas em que a Imperial Família honrara com a sua presença o espetáculo". Seria o "Regente, em nome do Imperador, o Sr. D. Pedro II" que estabeleceria a referida comissão, a qual seria composta do próprio Cândido José de Araújo Vianna e do Cônego Januário da Cunha Barbosa, e termina expressando a expectativa: "esperando do patriotismo de V. Exa. Que não hesitará em concorrer, por mais esta ocasião, com suas luzes para a civilização do País, prestando-se ao serviço que fica indicado". ${ }^{7}$

Mesmo havendo a determinação de que nenhuma peça fosse posta em cena sem ser para isto licenciada pelo juiz inspetor do teatro, os infratores receberiam uma multa de $30 \$ 000$ réis e teriam 8 dias de cadeia. O segundo paragrafo do artigo determina que os atores que apresentarem atitudes “desonestas, obscenas e ofensivas da moral pública serão multados em $10 \$ 000$ réis a $20 \$ 000$ réis e terão de 4 a 8 dias de prisão.

Essas normas legalmente deveriam ser aplicadas ao teatro de São Pedro, mas acabaram se estendendo às outras salas de espetáculo, à medida que elas foram se estruturando. A necessidade de regimentar as atitudes referentes aos teatros, seja do público seja dos artistas, caracteriza a urgência em estabelecer comportamentos considerados "civilizados" e reforçar os parâmetros morais da sociedade. O teatro estava no caminho dos hábitos sociais valorizados e a mudança de perspectiva entre essa arte e a sociedade, de maneira geral, também direcionaram as necessidades de gerir o comportamento do público fluminense.

Os artistas franceses chegaram ao Rio de Janeiro no meio do processo de regulamentação teatral aberto pelo documento de 1839, cuja comissão julgadora viria a constituir os membros do Conservatório Dramático Brasileiro, oficializado em 1843.

\footnotetext{
7 Biblioteca Nacional, setor de Manuscritos, Papeis avulsos do Conservatório Dramático Brasileiro, I-46, 5, 7, $\mathrm{n}^{\circ} 0011$.
} 
O Conservatório Dramático, aos olhos dos literatos que o idealizava, viria para suprir as lacunas deixadas pela criação da comissão de censura de 1839, pois esta era restrita ao teatro de São Pedro, mas "tornara-se premente seus trabalhos aos demais teatros da corte". Essa urgência em expandir o sistema censório aos outros teatros é coerente com o cenário que se impôs no Rio de Janeiro a partir da chegada da Companhia Francesa, em 1840. Quando as normas de 1839 foram reformuladas e estendidas também às outras salas de espetáculos, o repertório apresentado pelo teatro francês era outra fonte de inquietação, pois se tratava de vaudevilles e opéras-comiques, gêneros híbridos e que se mantiveram por muito tempo marginais na cultura francesa, mas que tinham alcançado lugar privilegiado durante o início do século XIX, sobretudo por terem se transformado em espaços de experimentação de estilos musical e literário e de crítica social.

Os artigos orgânicos da associação que formava o Conservatório foram aprovados pela Secretaria de Estado dos Negócios do Império, em 24 de abril de 1843. Mas, o Diário do Rio de Janeiro só publicou um pequeno artigo informando aos leitores a decisão do Imperador, em 2 de maio, dizendo que o Conservatório Dramático Brasileiro havia sido solenemente instalado em casa do Ilmo. Sr. Diogo Soares de Bivar, no dia 30 do mês de abril, achando-se presentes os Srs Sócios Instituídos.

A introdução desse documento anuncia que o objetivo do Conservatório é "promover os estudos dramáticos e o melhoramento da cena brasileira de modo que ela se torne a escola dos bons costumes e da língua". Mas, é no artigo $1^{\circ}$ que suas intenções de valorização do nacional são claramente expostas:

(...) seu principal intuito - animar e excitar o tallento nacional para os assunptos dramáticos e para as artes assessorias - corrigir os vícios da scena membros, os quais poderiam deliberar coletivamente, ou em separado, mas os pareceres seriam submetidos ainda ao conselho, vencendo o que obtivesse mais votação. As regras para o julgamento tinham por fundamento preestabelecido "a veneração à nossa santa religião; o respeito devido aos poderes políticos da nação e as autoridades constituídas; a guarda da moral 
e decência pública; a castidade da língua; e aquela parte que é relativa à ortoépica. ${ }^{8}$

A guarda da moral e da decência, assim como a veneração à religião não se apresentava apenas na censura dos textos literários das peças, mas também no respeito pelos costumes. O fechamento dos teatros na Quaresma ou a representação de peças apropriadas para o período eram dois deles. A autorização para a representação de determinadas peças também passou a ficar sob a responsabilidade do Conservatório Dramático. Em 1841, a Companhia Dramática Francesa, recém-chegada à corte, período em que o Rio de Janeiro não contava ainda com um órgão regulamentador dos teatros, manteve durante todo o período da quaresma o mesmo repertório cômico e a mesma frequência de representações que havia feito desde sua estreia. O diretor da Companhia expõe claramente as questões trazidas pelo estranhamento cultural:

Ne connaissant pas les usages du pays, je me suis laissé surprendre par l'époque du carême. Cependant, j'ai eu partie paré le coup que me menaçait, en réunissant avec peine des ouvrages mocouverts que par le montant approximatif de cet abonnement de trois soirées.

(...) prévenir le respectable public de vouloir bien remarquer combien il est urgent que la souscription soit remplie immédiatement pour la confection des décors, accessoires et costumes.

... les décors et accessoires seront point conformément à l'ouvrage. ${ }^{9}$

Em 1842, como forma de fazer com que o teatro francês respeitasse os hábitos locais, o Imperador deliberou que a Companhia suspendesse durante a quaresma suas representações, por constatar que a mesma não possuía peças próprias para aquele tempo. ${ }^{10} \mathrm{~A}$ medida foi comunicada à Companhia Francesa com a justificativa de que tendo ela colocado em cena, durante a quaresma do ano anterior, peças pouco apropriadas e considerando a carência de seu repertório

${ }^{8}$ Biblioteca Nacional, setor de Manuscritos, Papeis avulsos do Conservatório Dramático Brasileiro, L-II-34, 29, 039.

9 "Correspondências". Jornal do Commércio. 05/03/1841.

10 Biblioteca Nacional, setor de Manuscritos, Papeis avulsos do Conservatório Dramático Brasileiro, "Registro de ofício expedido por Candido José Viana sobre a Companhia Dramática Francesa, I-8, 25, 104. 
de títulos adequados para o período, ficaria suspensa de realizar apresentações nos dias determinados.

A crítica aos temas trazidos pelo repertório do teatro francês era direcionada exatamente pelos pontos propostos como fundamentais para a análise censória, que primava pela manutenção da moral, da religiosidade e também da linguagem.

Ao contrário da censura oficial do Conservatório Dramático, os críticos dos folhetins não aprovaram a proibição dos espetáculos do teatro francês e desde a chegada destes espetáculos na corte mantinham especial apreço pelas obras de Eugène Scribe.

As representações proporcionadas pelas críticas teatrais sobre as obras de Scribe são perpassadas pelos questionamentos vividos no momento, sobretudo a respeito da definição de identidade nacional do jovem país independente. Este discurso de formação de uma identidade brasileira é ligado ao conceito de civilidade e da necessidade que havia de civilizar os hábitos da corte. Neste contexto, nos discursos dos literatos brasileiros o teatro de Scribe tornou-se um instrumento de comparação entre a sociedade francesa civilizada e a brasileira que ainda precisava passar por este processo, funcionando como dispositivo disciplinar.

Dessa forma, as obras de Scribe foram consideradas como de vanguarda, produtos do tempo moderno, "do século XIX, de um país regido pelas formas representativas com liberdade de tribuna e de imprensa", "escreve o Folhetim do Jornal do Commércio. Apesar de representar a sociedade parisiense, tida como modelo de civilidade, os literatos brasileiros consideravam os costumes apresentados pelas obras de Scribe ainda distante da compreensão do novo país, como afirma o autor do Folhetim: "nossos hábitos e civilização distão muito dos hábitos e civilização da capital da França". ${ }^{2}$ No entanto, o valor atribuído pelo público francês à obra de Scribe era bastante ressaltado pelo Folhetim que, por

11 "FOLHETIM: Companhia Dramatica franceza- A Calumnia, comédia em cinco actos, por Scribe". In: Jornal do Commércio, 13-11-1841

12 "FOLHETIM: Theatro francez - La Camaraderie, comédie em 5 actos, por Scribe". In: Jornal do Commércio, 05-04-1842 
vezes, tece relações como na afirmação de que "o público elegante da capital da França não cessa de applaudir (obras de Scribe) três e quatro vezes por semana". ${ }^{13}$

\section{O julgamento controverso dos vaudevilles e opéra- comiques de Eugène Scribe}

Desde o início dos espetáculos apresentados pelos artistas franceses no Rio de Janeiro, os críticos teatrais foram unanimes a respeito da apreciação das obras de Scribe. Elas sempre eram bem elogiadas, com adjetivos de grande força positiva, como "vigorosa"; "veracidade inimitável”, "plenos", "engenhosos", "pleno de delicadeza e de espírito"; ainda caracterizavam o valor de seu texto com afirmações como: "Quem conhece as composições leves de Scribe, seus vaudevilles, quase sempre espirituosos, frescos e engraçados", publicava o Minerva Brasiliense, em 1843.

Por outro lado, no Rio de Janeiro, a percepção sobre os textos de Scribe muda a partir da formalização do Conservatório Dramático, em $1844 .{ }^{14}$ Neste momento, as obras julgadas pela polícia do teatro passaram às mãos dos censores do Conservatório, que tinham o direito legal de proibir as representações de obras que eles julgavam ser perigosas para a moral e os bons costumes necessários para promover a civilidade brasileira e manter os preceitos religiosos. No entanto, esta moral e costumes são marcados pela importância e o lugar que a religião ocupa na sociedade do Rio, considerando a tradição católica cultivada pela corte e a importante participação da igreja no poder da corte e no cotidiano da cidade.

Os vaudevilles não foram vistos como muito problemáticos pelos censores, com exceção de quando eram traduzidos, pois o texto em francês não apresentava o mesmo perigo que ele apresentava em português, por causa da dificuldade de compreensão do idioma de uma grande parcela do público. A maioria dos vaudevilles destinados ao exame censório pelas companhias francesas foram

\footnotetext{
13 “FOLHETIM: Beneficio de Mlle Caroline". In: Jornal do Commércio, 22-06-1842.

14 A "Corporação dos mùsicos" do Rio de Janeiro apresentou o projeto de criação do Conservatório Nacional em 13de agosto de 1838, mas ele só tornou-se oficial em 21 de janeiro de 1847, pelo decreto n. 492(52).
} 
autorizados, alguns com a indicação de supressões de palavras, ou frases, ou com a proibição de cenas, como aquelas com contato físico entre os atores, beijos, então, eram terminantemente vetadas. Outros foram proibidos apenas de serem representados na presença da Família Imperial e, o vaudeville La part du Diable, que já havia sido apresentado em 1841, foi proibido em 1844 , por causa da palavra Diabo do título e no meio da narrativa. ${ }^{15}$

Por outro lado, os literatos, críticos musicais e autores dos Folhetins afirmavam sua posição em relação às interdições do Conservatório Dramático, sobretudo quando as supressões não eram bem justificadas. Várias referências indiretas sobre as arbitrariedades dos censores eram publicadas nos Folhetins, com frases em tom sarcástico, enfatizando a falta de conhecimento sobre arte e literatura e de tato por parte dos censores, como: “Também parecerão exagerados ao leitor algum dos caracteres da comédia, mas é porque entre nós não estão ainda tão apurados as cabalas políticas e literárias, como na sociedade francesa". ${ }^{16}$

Por outro lado, são exatamente os opéras-comiques que representam os maiores problemas para os censores. Este gênero de teatro musical, ainda pouco conhecido pelo público e também pelos agentes da censura teatral, apresentava aos teatros brasileiros novas linguagens teatrais, tanto dramática quanto ao que se refere ao tema. Durante os anos de 1846-1848, os espetáculos de opéra-comique, no Rio de Janeiro, combinavam duas situações distintas: o sucesso de público e as preocupações da censura.

Em 27 de setembro de 1846, foi licenciada por Carlos Monteiro a peça La Dame Blanche, opéra-comique em 3 atos, de Scribe e Boieldieu, com o parecer dizendo que "nada tem que opõe a sua representação". No dia seguinte a Companhia Lírica Francesa já anunciava a sua estreia para o dia 29 do mesmo mês.

Outras duas peças tiveram pareceres favorável expedido por Carlos Monteiro, ainda no dia 27 de setembro: L'Ambassatrice, opéra-comique em 3

\footnotetext{
15 Todas as informações relativas às notas dos censores estão na Biblioteca Nacional, cetor de Manuscritos no Fundo Conservatório Nacional.

${ }^{16}$ FOLHETIM: Theatro francez - La Camaraderie, comédie em 5 actos, por Scribe. In: Jornal do Commércio, 05-04-1842
} 
atos, de Scribe e Auber, autorizada a ser levada à cena por "não conter doutrina oposta à religião e moral"; e Le Chalet, opéra-comique em um ato, de Scribe e Adam, cujo parecer dizia que já havia sido "licenciada com o título de Betty e cantada em italiano no teatro de São Pedro de Alcântara". Afirma o censor que a ópera "nada tem que ofenda a religião e os bons costumes e pode ser levada a cena cumprindo, porém, unicamente em respeito nas vias do país, que nos lugares marcados... guardo a primeira licença nas demonstrações de afeto entre as pessoas de diferentes sexos". Alguns meses após, no dia 28 de janeiro de 1846, José Rufino reforça a necessidade da supressão dos abraços existentes em três páginas do texto desta ópera.

Especialmente duas entre os opéra-comiques de Scribe apresentados na corte fizeram face à ambiguidade citada acima: Le domino noir e, sobretudo, Les diamants de la couronne. Le Domino Noir, opéra-comique em 3 atos, também de Scribe e Auber, não foi visto como tão conveniente aos interesses dos críticos do Conservatório brasileiro. José Dias Lima, a quem coube avaliar a obra, afirma ter lido com cautela, pois receava que o texto "com facilidade podia ter traços sutis da imoralidade por ele inoculado na mocidade, menos experiente talvez como a nossa a partir de um enredo bem tecido fascinando enfim seu bom senso". ${ }^{17}$ Por isso, deliberou que a peça não poderia ser representada na presença do Imperador sem as devidas supressões em algumas falas da personagem Jacinta e em trechos considerados libidinosos, como entre os convivas de Juliana, “indigna de ser representada". Várias supressões do texto ainda são sugeridas, alegando que tais alterações "não ofenderia a beleza do drama e o tornarão digno de ser representada na presença augusta do Imperador de um povo (...) que aspira ter bons costumes". ${ }^{18}$

A preocupação com a adequação do texto era severa a ponto de impor supressões em um texto de língua estrangeira, enquadrando aos parâmetros morais do Conservatório e, consequentemente, da elite intelectual fluminense,

\footnotetext{
17 Biblioteca Nacional, setor de Manuscritos, Papeis avulsos do Conservatório Dramático Brasileiro, I-8, 5, 6

18 Biblioteca Nacional, setor de Manuscritos, Papeis avulsos do Conservatório Dramático Brasileiro, I-8, 4, 54.
} 
tanto os franceses residentes no Rio de Janeiro quanto os poucos letrados brasileiros ou de outras nacionalidades que dominavam a língua francesa. Nesse caso, foram considerados indecorosos os termos escolhidos por Scribe para compor o texto e não o enredo em si, que descreve o ato de uma jovem que se fantasia com um dominó, ou seja, uma túnica negra com capuz, para poder participar de um baile sem que fosse notada.

Já Les diamants de la Couronne em tudo incomodou a moral dos censores brasileiros. A Companhia Lírica não foi a primeira a tentar colocar em cena este opéra- comique de Scribe e Auber, representado pela primeira vez, em março de 1841, no teatro do Opéra-Comique, em Paris.

Em 1844, o Conservatório Dramático Brasileiro registrou um pedido de licença para a representação de Les diamants de la Couronne. Na ocasião, o diretor do teatro francês já considerava que o enredo poderia apresentar problemas que levaria à sua proibição. $O$ texto original de Scribe narra a história de uma Rainha de Portugal, que face à delicada situação financeira em que encontrava o reino, decide vender as joias da coroa e substituí-las por replicas falsificadas. Para ser submetida ao exame censório, em 1844, a tática dos artistas da companhia francesa foi substituir o lugar onde se passa a trama de Portugal para a Suécia, para que o fato de ter como local de ação a antiga metrópole não fosse visto como uma ofensa à coroa brasileira, principalmente por tratar-se de uma rainha portuguesa falsária.

A manobra não deu certo e a peça foi proibida. Os argumentos de Francisco de Paulo de Azevedo, que na ocasião coloca-se contrário à representação da peça, apontam também para os exageros que ele acreditava ser propriamente romântico, assim ele argumenta que:

Ainda quando o enredo total da peça se fundasse em um fato histórico, eu não o consideraria bastante para que se representasse uma peça que representa não pouca imoralidade, pelo fato de vermos uma soberana, que se mete em farsas, à frente de uma quadrilha de ladrões, e convertida em protetora deles, embora se alegue a fim de utilidade por que ela empregou meios tão ignóbeis. Estes são sem dúvida reprovados por quem presa as 
prerrogativas da coroa, e visto mais por um tribunal de censura, sobre que pesa uma imediata responsabilidade moral a respeito de tais publicações. ${ }^{19}$

Esses pareceres emitidos na ocasião do pedido de representação da peça pela Companhia Dramática, feito em 1844, foram anexados ao novo pedido de avaliação feito pela Companhia Lírica, em 27 de setembro de 1846. Outra vez a peça de Scribe e Auber causou grande alvoroço entre os censores brasileiros.

O primeiro a negar a licença foi Diogo Bivar, o próprio diretor do Conservatório e responsável direto pela censura teatral. Para explicar sua decisão ele inicia o documento com a narrativa da peça, contando a disparatada colocação de uma figura Augusta portuguesa como parceira de falsários, concluindo em seguida que "se o autor do drama estudasse a história e geografia de Portugal francesa, então renegada pelos intelectuais brasileiros. Ele resume a repulsa por essa literatura francesa com a frase: "A literatura francesa é o gênio da destruição". ${ }^{20}$

No mesmo documento, Tomas do Nascimento Silva tenta explicar o porquê da sua posição contrária à representação da ópera. A defesa da honra da família real era o foco de seu argumento. Contra a peça francesa, a defesa dos portugueses era evidente, mesmo sendo eles os ex-colonizadores, de quem os literatos brasileiros tentavam desvencilhar a identidade da nova nação.

Entendidas as possibilidades oferecidas pelo censor, o diretor da Companhia Francesa submete outra vez a peça à análise, em dezembro de 1846. No documento em anexo ao pedido, ele descreve as modificações:

La scène se passe en Danemark, en 1387, à la fin du reine de Waldemar III et de sa fille Marguerita. Les deux premiers actes ... environs de Luden, et la troisième à Copenhague. ${ }^{21}$

\footnotetext{
19 Biblioteca Nacional, setor de Manuscritos, Papeis avulsos do Conservatório Dramático Brasileiro, I-8, 5, 48. Documento 5.

20 Biblioteca Nacional, setor de Manuscritos, Papeis avulsos do Conservatório Dramático Brasileiro, I-8, 5, 48. Documento 5.

${ }^{21}$ Biblioteca Nacional, setor de Manuscritos, Papeis avulsos do Conservatório Dramático Brasileiro, I-8, 5, 48. Documento 5.
} 
Com as mudanças sugeridas por Levasseur, diretor da Companhia, Camilo José do Rosário emite o requerimento de liberação da peça "com a total mudança da situação de cena e nomes de personagens, ficando assim transpor elementos que evidenciavam costumes portugueses. No entanto, eram roupas que se enquadravam nos hábitos condizentes ao período". ${ }^{22}$

A confirmação de João Caetano de que o figurino seria todo com características da Idade Média segue a proposta de transposição temporal da trama, para a data de 1387, e o afastamento da mesma, pelo menos em tese, de qualquer semelhança que remetesse ao reino português.

Em dezembro de 1846, José Pinto Lopez ainda faz um adendo sobre sua posição a favor da representação da ópera. Segundo ele, além das modificações, não vê grandes problemas, pois o texto não é escrito em português e não será recitado, caso em que teria algumas observações a fazer, como é em francês e cantada poderia passar. Assim, em 31 do mesmo mês, Diogo Bivar, presidente do Conservatório, assina

o ato de autorização da peça, com a conclusão de que "mudaram-se os nomes das personagens, mudarão o lugar da ação e todo o que pudesse ter relação com as atuais casas reinantes do Brasil e Portugal, e mesmo com o reino de Portugal em seu passado". ${ }^{23}$

Autorizada, a estreia da peça no teatro de São Francisco começou a ser anunciada nos jornais, em $1^{\circ}$ de janeiro de 1847, ao mesmo tempo em que o teatro de São Pedro de Alcântara representava, pela Companhia Italiana, La fille du Régiment, de Donizetti. Seis anos separaram a estreia dessa obra de Auber e Scribe no teatro Favart, em Paris, de sua primeira representação no Rio de Janeiro.

Como efeito contrário, a recusa do pedido de liberação da peça feito pela Companhia Francesa ao Conservatório, mais o posicionamento da crítica que tendia a favor do teatro francês, fez com que crescesse a indignação do público e os assíduos frequentadores da plateia da Companhia Lírica começavam a maldizer

\footnotetext{
22 Biblioteca Nacional, setor de Manuscritos, Papeis avulsos do Conservatório Dramático Brasileiro, 1-8, 5, 48. Documento 5.

${ }^{23}$ Biblioteca Nacional, setor de Manuscritos, Papeis avulsos do Conservatório Dramático Brasileiro, I-8, 5, 48. Documento 5.
} 
a "absurda severidade que os privavam de uma das melhores do repertório français". ${ }^{24}$ Por outro lado, mesmo com as estruturas da censura, depois da mudança de Portugal por Dinamarca dentro do texto, o Folhetim do Jornal do Commércio conclui com essas modificações "que espantoso milagre se operou, a ópera não é mais antimonarquista!"25

A medida tomada pela Companhia Francesa foi valorizada pela crítica taxando o comportamento do Conservatório Dramático como "inquisitorial" . De fato, aos olhos da crítica, a modificação da ação da peça, por parte da Companhia Francesa, deixando de situar o enredo em Portugal, transferindo-o para o Reino da Dinamarca, para o crítico do folhetim,

deixa claro e evidente que a imoralidade da ópera assim desapareceria, e o Conservatório Brasileiro, que é o juiz da matéria, decidiu magistralmente que qualquer rainha podia vender os seus brilhantes, menos a de Portugal. Mas seja como for, veio a licença que é o que importa, e os "Diamants de la Couronne". ${ }^{26}$

Segundo Antônio Candido, em seus estudos sobre a crítica teatral, a valorização do contexto no qual a obra está inserida funciona como "agente da estrutura" da crítica teatral dos Folhetins, sendo a "procura dos elementos responsáveis pelo aspecto e significado da obra" (Candido, 2000, p. 7). No caso das considerações sobre a ópera Les diamants de la couronne, as colocações sobre a postura do Conservatório vai além da simples função de "agente de estrutura" para explicar a obra e o desempenho dos atores, enfatiza também o desencontro de opiniões e ponto de vista sobre a literatura e sua função, característico do período de mudanças de paradigmas, no que diz respeito às artes, em que se encontrava o Rio de Janeiro na década de 1840.

\footnotetext{
24 "Companhia lyrica francesa: Les diamants de la couronne", Jornal do Commercio, 14/01/1847, p. 02.

25 "Companhia lyrica francesa: Les diamants de la couronne", Jornal do Commercio, 14/01/1847, p. 02.

${ }^{26}$ Theatro de S Francisco: Os diamantes da coroa". In Jornal do Commercio, 17/01/1847, p. 01.
} 


\section{Fontes}

Manuscritos

Fundo Conservatório Dramático Nacional. Biblioteca Nacional do Rio de Janeiro, Divisão de Manuscritos.

\section{Periódicos}

Jornal do Commércio

Diário do Rio de Janeiro

Minerva Brasiliense

\section{Referências}

BENTLEY, Eric. O teatro engajado. Tradução por Yan Michalski. Rio de Janeiro: Zahar, 1969. 180 p. Tradução de: The theatre of commitment.

BOURDIEU, Pierre. O poder simbólico. Tradução por Fernando Tomaz. 3. ed. Rio de Janeiro: Bertrand Brasil, 2000

CANDIDO, “A. Crítica e Sociologia”. In: . Literatura e Sociedade. São Paulo: R. A. Queiroz, Publifolha, 2000.

CARNEIRO, Maria Luiza Tucci (org.) Minorias silenciadas: a história da censura no Brasil. São Paulo: EDUSP: Imprensa Oficial do Estado: FAPESP, 2002.

CHARTIER, Roger. A História cultural: entre práticas e representações. Tradução por Maria Manuela Galhardo. Lisboa: Difel, [s/d]. p. 16-17.

COUVEUR, Manuel; VENDRIX, Philippe. L'opéra-comique en France au XIX siècle, Liège: Madarga.

COSTA, Cristina. Censura em cena: teatro e censura no Brasil. São Paulo: Edusp, Fapesp, Imprensa Oficial, 2006.

GAY, Peter. Une culture bourgeoise 1815-1914: Londres, Paris, Berlin... Biographie d'une classe sociale. Éditions Autrement, Collection Mémoires no 113.

LACOMBE, Hervé. Les voies de l'opéra français au XIXe siècle. Paris: Fayard, 1997.

LEGRAND, Raphaëlle. Regards sur l'opéra-comique: trois siècles de vie théâtrale. Paris: CNRS Editions, 2002.

MALERBA, Jurandir. A corte no exílio: civilização e poder no Brasil às vésperas da independência (1808-1821). São Paulo: Cia das Letras, 2000. 
MAMMì, Lorenzo. “Teatro em música no Brasil monarquico”. In: JANCSÓ, Instván; KANTOR, Iris (org). Festa: cultura e sociabilidade na América Portuguesa. Vol 1. São Paulo: Hucitec, 2001.

NERVAL, Gérard de. Oeuvres complètes. Paris: Gallimard, 1989, p. 785

PENDLE, Karin Swanson. Eugène Scribe and French Opera of the Nineteenth Century. Ph.D. University of Illinois, 1970. 